\title{
Cell Wall Components of Candida albicans as Immunomodulators: Induction of Natural Killer and Macrophage-mediated Peritoneal Cell Cytotoxicity in Mice by Mannoprotein and Glucan Fractions
}

\author{
By LUCIA SCARINGI, ${ }^{1}$ PIERFRANCESCO MARCONI, ${ }^{1}$ \\ MARIA BOCCANERA, ${ }^{2}$ LUCIANA TISSI, ${ }^{1}$ FRANCESCO BISTONI ${ }^{1}$ \\ AND ANTONIO CASSONE ${ }^{2 *}$ \\ ${ }^{1}$ Institute of Medical Microbiology, University of Perugia, Perugia, Italy \\ ${ }^{2}$ Medical Mycology Unit, Istituto Superiore di Sanità, 00161 Rome, Italy
}

(Received 20 October 1987; revised 9 December 1987)

\begin{abstract}
Cell wall components from Candida albicans were compared to intact cells for their ability to induce natural cytotoxic immunoeffectors in the peritoneal cavity of mice. A soluble mannoprotein extract (MP) and an insoluble glucan fraction (GG) strongly stimulated the generation of peritoneal effectors capable of lysing YAC-1 and P-815 tumour cell lines in vitro. The anti-YAC-1 effectors were characterized as natural killer (NK) lymphocytes while the antiP-815 effectors appeared to be activated macrophages. The activity of each fraction was typically dose-dependent and both fractions differed from whole cells in the kinetics of induction of cytotoxicity. However, the NK and macrophage effectors generated by these materials had similar functional and phenotypic properties, irrespective of the material used as inducer. No mannoprotein was detected in the insoluble glucan fraction GG. Hence, the immunoenhancing activity of GG could not be attributed to the presence of some MP or MPlike component. Mannan-rich fractions with low $(<3 \%)$ protein content $(\mathbf{M})$ or extracted by hot alkaline reagent (M-alk) were inactive as NK and macrophage inducers. Thus, the cell wall of C. albicans contains at least two distinct macromolecular complexes which mediate the induction in murine peritoneal exudates of cytotoxic effectors active against tumour cell lines.
\end{abstract}

\section{INTRODUCTION}

Injection of Candida albicans into immunocompetent hosts induces a number of non-specific immunomodulatory effects (Cassone et al., 1981; Cutler \& Lloyd, 1983; Domer et al., 1986). This property is shared by other micro-organisms and their products, and by some non-microbial compounds; but the immunomodulating properties of $C$. albicans deserve special attention since this fungus forms part of the human commensal flora, and hence its effects on the immune system are likely to be relevant under natural conditions. Healthy individuals are sensitized to this fungus and capable of mounting diverse immune responses when suitably challenged with C. albicans antigens (Rogers \& Balish, 1980; Tartof et al., 1980, 1983; Ausiello et al., 1986). These responses may lead to protection against aggressive tumours or infectious agents in experimental models (Kokoshis et al., 1978; Williams et al., 1978; Marconi et al., 1983; Bistoni et al., 1986). For this reason, C. albicans should be regarded as a powerful biological response modifier: these are materials from microbial or non-microbial sources important for their potential applications as immunoprophylactic or therapeutic agents in the fields of cancer and/or infectious diseases.

One rather common property of biological response modifiers is the induction or augmentation of natural immunoreactivities including, in particular, the natural killer (NK) cell

Abbreviations: NK, natural killer; PEC, peritoneal exudate cells. 
activity (Herberman \& Ortaldo, 1981; Zang et al., 1986). We have previously demonstrated that injection of chemically inactivated yeast cells of $C$. albicans into the peritoneal cavities of mice induced the appearance of an effector population with potent cytotoxicity against the YAC-1 tumour cell line. These effectors had the phenotypic characteristics of murine NK lymphocytes (Marconi et al., 1985). In an attempt to correlate microbial structure to immunological activity, we have now investigated whether certain isolated cell wall components of $C$. albicans could mediate effector induction when injected into the peritoneal cavity of mice.

\section{METHODS}

Mice. Hybrid (Balb/c $\mathrm{Cr} \times \mathrm{DBA} / 2 \mathrm{Cr}) \mathrm{F} 1\left(\mathrm{CD} 2 \mathrm{~F} 1 \mathrm{H}-2^{\mathrm{d}} / \mathrm{H}-2^{\mathrm{d}}\right)$ specific pathogen-free female mice were obtained from Charles River Breeding Laboratories. They were 8-9 weeks old at the start of each experiment.

Candida albicans and cell wall fractions. The strain of $C$. albicans used throughout this study (strain BP) was isolated from clinical material. Cultivation, inactivation and lyophilization of the micro-organism were as described elsewhere (Mattia \& Cassone, 1979; Marconi et al., 1985). The lyophilized intact cells (1 mg of dry material, corresponding to approximately $5 \times 10^{7}$ cells) were suspended in sterile $0.85 \% \mathrm{NaCl}$ immediately before use: this material is referred to as CA.

Cell wall fractions were prepared from washed cell pellets before cell inactivation, essentially as described elsewhere (Cassone et al., 1981; Ausiello et al., 1986). Briefly, a mannoprotein extract was obtained by autoclaving washed yeast cells $\left(140^{\circ} \mathrm{C}, 2 \mathrm{~h}\right)$ and precipitating the supernatant in cold ethanol as described by Sutherland \& Wilkinson (1971). After deproteination with chloroform/butanol, the aqueous phase was extensively dialysed against $\mathrm{H}_{2} \mathrm{O}$, then lyophilized. The lyophilized powder (about $35 \mu \mathrm{g}$ from $1 \mathrm{mg}$ of dry cells) was dissolved to a concentration of $10 \mathrm{mg} \mathrm{ml}^{-1}$, in Tris/ $\mathrm{HCl}$ buffer $(0.05 \mathrm{M}, \mathrm{pH} 7.5)$ containing $10 \mathrm{mM}-\mathrm{MgCl}_{2}$, and passed through a $5 \mathrm{ml}$ column of Concanavalin A-Sepharose 4B (Sigma) washed and pre-equilibrated in the same buffer. More than $90 \%$ of the total carbohydrate-positive material was strongly retained by the gel. It was eluted with $0.5 \mathrm{M}-\mathrm{methyl} \alpha-$ D-mannoside $(15 \mathrm{ml}, 2 \mathrm{~h}$ ). The eluted material was precipitated in cold ethanol, washed and redissolved in water, then extensively dialysed against water and lyophilized. This material was referred to as MP (about $26 \mu \mathrm{g}$ from $1 \mathrm{mg}$ of dry cells). A mannoprotein extract obtained from Saccharomyces cerevisiae by a procedure identical to that reported above for the MP fraction from C. albicans was used as a control in ELISA inhibition experiments (see below).

A low-protein mannan fraction (M) was prepared as described by Peat et al. (1961). M-alk was a mannan-rich preparation obtained by hot alkali extraction of cell walls as reported by Sutherland \& Wilkinson (1971). Clean walls were prepared after cell breakage with $0.45 \mathrm{~mm}$ glass beads followed by extensive water washing, essentially as described by Cassone et al. (1979) with the addition of a final wash in $0.01 \mathrm{M}$-acetic acid at $4{ }^{\circ} \mathrm{C}$ to facilitate removal of cytoplasmic debris.

Finally, an insoluble glucan fraction in the form of glucan 'ghosts' (GG) was obtained from cell walls by cycles of acid and alkali extractions at $100^{\circ} \mathrm{C}$, as described by Cassone et al. $(1978,1981)$.

Each extract or fraction was subjected to a gelification test with limulus lysate to detect bacterial endotoxin. All tests were negative. Each material, at the desired concentration, was injected intraperitoneally in a final volume of $0.25 \mathrm{ml}$ sterile saline. After each treatment (days 1, 3, 7 and 14), peritoneal exudate cells (PEC) were removed, counted and evaluated for morphology and staining characteristics in Giemsa and Wright's stained cytocentrifuge preparations.

Analytical determinations. Total protein was determined by the Folin method using bovine serum albumin as the standard. For the insoluble glucan fraction, the assay was done on the extract obtained by boiling the fraction in $1 \mathrm{M}-\mathrm{NaOH}\left(10 \mathrm{~min}, 100^{\circ} \mathrm{C}\right)$. Total polysaccharide was determined by the phenol/sulphuric acid method according to Dubois et al. (1956) using glucose as the standard. Total phosphorus of mannan fractions was assayed by the method of Chen et al. (1956). Sugar composition of fractions from C. albicans was analysed by gas-liquid chromatography using a procedure essentially similar to that of Albersheim et al. (1967). Chromatography was performed with a Carlo Erba Fractovap, model $2101 \mathrm{AC}$, equipped with a flame ionization detector. The alditol acetates were separated in a glass column $(3 \mathrm{~mm} \times 300 \mathrm{~cm})$ containing 3\% SP 2930 on Supelcoport 100-120 mesh column packing, at a temperature of $190^{\circ} \mathrm{C}$ and under a nitrogen flow of $25 \mathrm{ml} \mathrm{min}{ }^{-1}$. The instrument was equipped with a Hewlett-Packard (model 3380A) recorder/integrator. Internal standards were used to calculate the concentration of single monosaccharides from the peak area and retention time.

Enzyme-linked immunosorbent assay (ELISA). Assays were done in polystyrene microtitration plates (Dynatech). Antigenic fractions $\left(200 \mu \mathrm{l}, 5 \mu \mathrm{g} \mathrm{ml} \mathrm{m}^{-1}\right.$ in $0 \cdot 2 \mathrm{M}$-sodium carbonate buffer) were added to the wells, incubated overnight at $4{ }^{\circ} \mathrm{C}$ and subsequently rinsed (three times) with phosphate-buffered saline (PBS; containing, per litre, $0.2 \mathrm{~g} \mathrm{KH}_{2} \mathrm{PO}_{4}, 2.9 \mathrm{~g} \mathrm{Na}_{2} \mathrm{HPO}_{4} .12 \mathrm{H}_{2} \mathrm{O}, 0.2 \mathrm{~g} \mathrm{KCl}$ and $\left.8 \mathrm{~g} \mathrm{NaCl} ; \mathrm{pH} 7.4\right)$ containing Tween $20(0.05 \%$, v/v). Hyperimmune human serum $(200 \mu \mathrm{l})$ (ELISA titre with MP as coating antigen $1: 128000)$ from a candidosis- 
convalescent donor was added at the desired dilution in PBS, and the plates were incubated for $1 \mathrm{~h}$ at room temperature. After careful washings with Tween 20/PBS buffer, $200 \mu \mathrm{l}$ of a $1: 1000$ dilution in PBS of goat antihuman IgG-alkaline phosphatase conjugate (Sigma) was added for $1 \mathrm{~h}$ and enzyme activity was detected by adding nitrophenyl phosphate reagent [ $p$-nitrophenyl phosphate, $1 \mathrm{mg} \mathrm{ml}^{-1}$ in diethanolamine buffer composed of diethanolamine, $9 \cdot 7 \%(\mathrm{v} / \mathrm{v}) ; \mathrm{MgCl}_{2}, 10 \%(\mathrm{w} / \mathrm{v})$, adjusted to $\mathrm{pH} 9 \cdot 8$ with $\left.1 \mathrm{M}-\mathrm{HCl}\right]$. The reaction was terminated by adding $40 \mu \mathrm{l} 3 \mathrm{M}-\mathrm{NaOH}$ after $20 \mathrm{~min}$.

ELISA-inhibition experiments were also performed with cell wall fractions. Each fraction was added, at suitable concentration, to the hyperimmune human serum and incubated overnight at room temperature. The mixtures were then added to antigen (MP)-coated wells and the immunosorbent assay performed as described above. The ELISA tests were read with a Titertek Multiscan set at $405 \mathrm{~nm}$ and blanked against air. Tests were done in triplicate and the $A_{405}$ of the well without a $C$. albicans coating antigen (usually $0 \cdot 14-0 \cdot 12$ ) was taken as the background reading. A positive test was one with at least twice the absorbance of the background reading. The degree of ELISA-inhibition by the cell wall fractions was calculated by the formula $\left(A_{405}^{\mathrm{T}}-A_{405}^{\mathrm{I}}\right) /\left(A_{405}^{\mathrm{T}}-A_{405}^{\mathrm{B}}\right)$, where $A_{405}^{\mathrm{l}}$ was the reading of the wells containing the inhibitor, and $A_{405}^{\mathrm{T}}$ and $A_{405}^{\mathrm{B}}$ the readings of the wells without inhibitor or coating antigen, respectively. All readings were calculated as means $( \pm \mathrm{SD})$ of triplicate tests. The sensitivity of the inhibition assay involving MP both as coating and liquid-phase serum-ligand was in the range $1-2 \mathrm{ng} \mathrm{ml}^{-1}$.

Tumours. Cell lines YAC-1 (a tissue-culture cell line of YAC, a Moloney virus-induced lymphoma in an A/Sn mouse: Cikes et al., 1973) and P-815 (derived from methylcholanthrene-induced mastocytoma in a DBA/2: Gilbertson et al., 1986) were maintained in RPMI 1640 medium (Eurobio Laboratories) supplemented with $10 \%$ ( $\mathrm{v} / \mathrm{v}$ ) foetal calf serum (GIBCO Laboratories), $25 \mathrm{mM}$-HEPES buffer and $0 \cdot 1 \%(\mathrm{w} / \mathrm{v})$ gentamicin sulphate (this medium is referred to as complete RPMI 1640 medium). Tumour cells were transferred into fresh, complete RPMI 1640 medium $24 \mathrm{~h}$ before use in the ${ }^{51} \mathrm{Cr}$ release assay.

Cell fractionation procedures. The adherence and phagocytic properties of PEC effectors elicited by cell wall fractions from C. albicans were evaluated as previously reported (Marconi et al., 1985). In particular, passage of effector cells over a nylon-fibre column was done as described by Julius et al. (1973) while phagocytic cells were removed from the effector population as reported by Landolfo et al. (1978). Percoll-density gradients were prepared as described by Santoni et al. (1985).

Treatment with anti-Thy1.2 antiserum and complement. Monoclonal antibodies to Thy1.2 were purchased from New England Nuclear (lot LK 1Q4). Effector cells $\left(3 \times 10^{7}\right)$ were preincubated with anti-Thyl.2 antiserum diluted 1 in 100 in complete RPMI 1640 medium for $30 \mathrm{~min}$ at room temperature, washed once in the same medium, suspended in a 1 in 4 dilution of rabbit complement (Cederlane Laboratories) and incubated for $45 \mathrm{~min}$ at $37^{\circ} \mathrm{C}$. The surviving cells were then washed twice and counted. In all experiments, a complement control was included in which the first incubation was in medium alone and the second incubation was with the complement. The efficiency of the anti-Thyl.2 serum in killing $\mathrm{T}$ cells was checked by an indirect immunofluorescence assay. PEC recovered after treatment with the anti-Thy 1.2 serum (recovery in the range $47-52 \%$ ) were treated with a 1 in 5 dilution of fluoresceinated anti-mouse immunoglobulin (Cappel, Cooper Biomedical) for $45 \mathrm{~min}$ at $4{ }^{\circ} \mathrm{C}$. After three washes, cells were observed for the number of fluorescence-positive elements. As a further control, mouse thymocytes, obtained by standard techniques, were subjected to a treatment with anti-Thy1.2 serum identical to that described above for PEC and the percentage of Thy1.2-positive cells was determined by the immunofluorescent assay, as reported above.

Treatment with anti-asialo GMI serum and complement. Asialo GM1 antiserum, previously shown to react selectively with mouse NK cells (Kasai et al., 1980), was obtained from Wako Chemicals. PEC were treated with a 1 in 200 dilution of antiserum in RPMI 1640 medium for $30 \mathrm{~min}$ at room temperature, washed twice, suspended in a 1 in 4 dilution of rabbit complement and incubated for $1 \mathrm{~h}$ at $37^{\circ} \mathrm{C}$. Surviving cells were washed twice, counted and analysed for morphology and staining characteristics before testing their cytotoxic activity (see below).

In vitro cytotoxicity assay. (i) Preparation of effector cells. PEC were harvested by massaging the peritoneal cavity after injection of $5 \mathrm{ml}$ cold complete RPMI 1640 medium containing $5 \mathrm{U}$ heparin $\mathrm{ml}^{-1}$ and aspirating the exudate with a syringe with a 26-gauge needle. Cells were centrifuged and washed three times in cold complete RPMI 1640 medium. Cells resuspended in complete RPMI 1640 medium were counted with a haemocytometer and their viability assessed by the dye (trypan blue $0.05 \%$, w/v) exclusion method. All cells were kept on ice until use.

(ii) ${ }^{51} \mathrm{Cr}$ release assay. The assay described by Marconi et al. $(1983,1985)$ was used. Different concentrations of effector cells were incubated with $10^{4}{ }^{51} \mathrm{Cr}$-labelled tumour target cells $\left(5 \times 10^{6}\right.$ cells labelled with $100 \mu \mathrm{Ci}$ $\mathrm{Na}_{2}{ }^{51} \mathrm{CrO}_{4}$ for $45 \mathrm{~min}$ ) for different times at $37^{\circ} \mathrm{C}$ in $\mathrm{U}$-shaped 96-well plastic microtitre plates (Greiner Labortechnik). The release time was $4 \mathrm{~h}$ from YAC-1 target cells and $18 \mathrm{~h}$ from P-815 target cells. After incubation, the plates were centrifuged at $800 \mathrm{~g}$ for $10 \mathrm{~min}$ and the radioactivity present in $0.1 \mathrm{ml}$ of the supernatant was measured with a $\gamma$-scintillation counter. All groups were tested in quadruplicate. The base-line ${ }^{51} \mathrm{Cr}$ release value was determined by using an autologous control with equal numbers of unlabelled target cells in 
Table 1. Chemical composition of whole cells and fractions of C. albicans

All values are expressed as a percentage of lyophilized material. The values for protein, polysaccharide and phosphorus are means \pm SD of three determinations performed with three different preparations. For gas-liquid chromatography of individual sugar components, the different preparations were pooled and used for two independent runs: the results are expressed as means \pm SD.

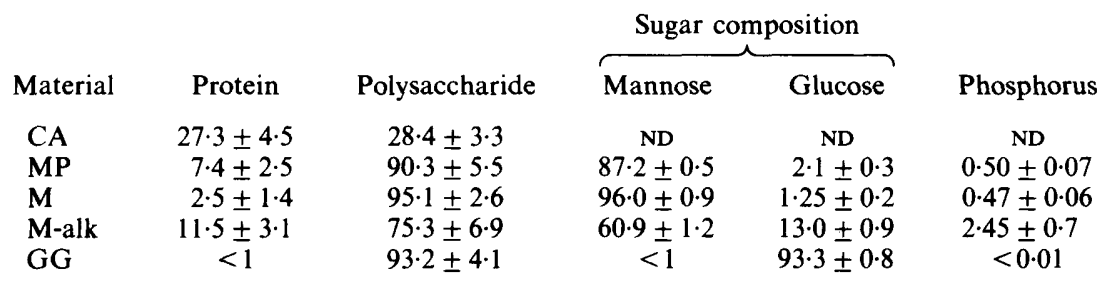

ND, Not done.

place of the effector cells. The percentage of specific lysis was obtained as follows: percentage cytotoxicity $=[$ (test c.p.m. - autologous c.p.m.)/(total c.p.m. incorporated/2)] $\times 100$, where test c.p.m. was the mean c.p.m. released in the presence of effector cells.

Statistical analysis. Differences in specific radiolabel released in the in vitro microtoxicity assays were determined by using Student's $t$ test. Each experiment was repeated three to five times; the data reported are the means of quadruplicate samples. Standard errors (usually less than $1.5 \%$ ) have been omitted.

\section{RESULTS}

\section{Crude chemical composition and antigenicity of cell wall fractions}

Cell wall fractions from $C$. albicans were analysed for their polysaccharide and protein composition. Table 1 shows that each fraction was predominantly or almost exclusively composed of polysaccharide. All the soluble extracts (MP, M, M-alk) contained mannan as principal, if not sole, carbohydrate whereas the insoluble GG fraction was practically pure glucan. With the exception of M-alk, glucose was always a minor constituent of the mannan extracts while ribose was detectable only in the MP fraction. Protein was also present in all the mannan fractions. In particular, the MP fraction had a markedly higher protein content than the $\mathbf{M}$ fraction. All mannan fractions were phosphorylated.

MP and $M$ fractions worked with comparable efficiency as solid-phase (coating) antigens in indirect ELISA to detect anti-mannan antibodies in human serum. The three mannan fractions from $C$. albicans, but not mannan from $S$. cerevisiae, were also highly (and comparably) active as liquid-phase ligands as shown by the fact that they inhibited the ELISA assay with MP (or M) as solid-phase antigen and an anti-C. albicans hyperimmune human serum (haemagglutination titre $1: 640)$ as antibody. The inhibition was nearly complete $(>90 \%)$ at a concentration of $50 \mathrm{ng}$ $\mathrm{ml}^{-1}$ of each fraction. In contrast, the insoluble glucan was inactive both as coating antigen and as inhibitor even when used in large excess (i.e. $300 \mathrm{ng} \mathrm{ml}^{-1}$ ) with respect to MP as coating antigen.

\section{Effect of intraperitoneal injection of $C$. albicans and its cell wall fractions on cell number and composition of peritoneal exudate}

The intraperitoneal injection of microbial cells and their components, as for many nonspecific irritants or immunomodulators, provokes a strong inflammatory response, with fluid and cellular exudate. In the case of injection of $C$. albicans and its fractions, the peritoneal exudate showed the number and type of cells shown in Table 2.

Whole yeast cells (CA) induced, $3 \mathrm{~d}$ after injection, the highest cellularity in the peritoneal exudate, which contained about three times more leucocytes than the exudate from untreated control mice. Fewer cells were obtained from mice given cell wall fractions (MP, M-alk, GG) whatever the day of harvesting. Although the composition of the exudate varied rather 
Table 2. Effect of intraperitoneal injection of C. albicans and its cell wall fractions on the leucocyte composition of the peritoneal exudate

\begin{tabular}{|c|c|c|c|c|c|c|c|}
\hline \multicolumn{3}{|c|}{ Treatment } & \multirow{2}{*}{$\begin{array}{l}10^{-6} \times \text { Total } \\
\text { no. of PEC }\end{array}$} & \multicolumn{4}{|c|}{ PEC composition $(\%)$} \\
\hline Material & Dose (mg) & Time (d) & & PMN & Ly & $\mathrm{LGL}+\mathrm{M} \Phi-\mathrm{p}$ & $\mathbf{M} \Phi$ \\
\hline None & - & - & $1 \cdot 2 \pm 0.05$ & $1 \cdot 0$ & $2 \cdot 0$ & 0.0 & 97 \\
\hline $\mathrm{CA}$ & 1 & 3 & $3 \cdot 3 \pm 0.4$ & $15 \cdot 5$ & $11 \cdot 5$ & $34 \cdot 5$ & $38 \cdot 5$ \\
\hline $\mathrm{CA}$ & 1 & 7 & $1.8 \pm 0.2$ & $3 \cdot 5$ & $20 \cdot 5$ & $52 \cdot 0$ & $24 \cdot 0$ \\
\hline MP & 0.01 & 3 & $2 \cdot 0 \pm 0 \cdot 2$ & $11 \cdot 0$ & $23 \cdot 0$ & $40 \cdot 0$ & $26 \cdot 0$ \\
\hline GG & 1 & 7 & $2 \cdot 5 \pm 0 \cdot 3$ & $21 \cdot 0$ & $28 \cdot 5$ & $36 \cdot 0$ & $18 \cdot 5$ \\
\hline M-alk & $0 \cdot 1$ & 1 & $2 \cdot 1 \pm 0.2$ & $27 \cdot 0$ & $10 \cdot 0$ & $36 \cdot 0$ & $27 \cdot 0$ \\
\hline
\end{tabular}

Table 3. Cytolytic anti-YAC-1 activity of PEC from mice injected with extracts from $C$. albicans: a typical dose-response experiment

Whole cells (CA) and cell wall fractions were injected intraperitoneally into 8-week-old CD2F1 mice, at the indicated doses. After 3 and $7 \mathrm{~d}$, PEC were harvested and used in a $4 \mathrm{~h}{ }^{51} \mathrm{Cr}$ release assay against YAC-1 target cells, at an effector: target ratio of $50: 1$.

\begin{tabular}{|c|c|c|c|}
\hline \multirow[b]{2}{*}{ Treatment } & \multirow{2}{*}{$\begin{array}{l}\text { Dose } \\
(\mathrm{mg})\end{array}$} & \multicolumn{2}{|c|}{ Percentage specific cytotoxicity } \\
\hline & & Day 3 & Day 7 \\
\hline None & - & $5 \cdot 1$ & $4 \cdot 7$ \\
\hline $\mathrm{CA}$ & $\begin{array}{l}0 \cdot 01 \\
1 \\
5\end{array}$ & $\begin{array}{l}17 \cdot 4^{*} \\
36 \cdot 5^{*} \\
26 \cdot 9^{*}\end{array}$ & $\begin{array}{l}16 \cdot 9^{*} \\
41 \cdot 4^{*} \\
32 \cdot 5^{*}\end{array}$ \\
\hline MP & $\begin{array}{l}0.005 \\
0.01 \\
0.1\end{array}$ & $\begin{array}{l}12 \cdot 4 \\
39 \cdot 0^{*} \\
21 \cdot 0^{*}\end{array}$ & $\begin{array}{l}\text { ND } \\
6 \cdot 2 \\
9 \cdot 8\end{array}$ \\
\hline GG & $\begin{array}{l}0 \cdot 01 \\
0.5 \\
1.0 \\
2.0\end{array}$ & $\begin{array}{c}9 \cdot 2 \\
11 \cdot 2 \\
19 \cdot 4^{*} \\
15 \cdot 7\end{array}$ & $\begin{array}{l}12 \cdot 0 \\
16 \cdot 7 \\
31 \cdot 2^{*} \\
26 \cdot 4^{*}\end{array}$ \\
\hline $\mathbf{M}$ & $\begin{array}{l}0 \cdot 01 \\
0 \cdot 1 \\
1\end{array}$ & $\begin{array}{r}9.5 \\
6.4 \\
13.7\end{array}$ & $\begin{array}{l}\text { ND } \\
5 \cdot 3 \\
6 \cdot 0\end{array}$ \\
\hline M-alk & $\begin{array}{l}0.01 \\
0.1 \\
0.5\end{array}$ & $\begin{array}{r}8 \cdot 3 \\
11 \cdot 6 \\
7 \cdot 4\end{array}$ & $\begin{array}{l}6 \cdot 6 \\
4 \cdot 7 \\
7 \cdot 2\end{array}$ \\
\hline
\end{tabular}

ND, Not done.

* A highly significant difference $(P<0.01)$ in the specific cytolysis by PEC from treated mice versus those from untreated controls.

significantly, depending upon the injected material, 'granulated-cytoplasm' cells, i.e. large granular lymphocytes and macrophage-precursors were generally prevalent, most notably after the injection of whole cells $(52 \%$, on day 7$)$ and $\mathrm{MP}(40 \%$, on day 3$)$. The M-alk fraction was the only material that elicited a relatively neutrophil-rich exudate $(27 \%$, on day 1$)$; MP and GG produced a peritoneal exudate with a relative abundance of small lymphocytes $(23 \%$, on day 3 and $28.5 \%$ on day 7 , respectively). Macrophages, usually the sole type of cell in normal peritoneal exudate, comprised only about $25 \%$ of the total PEC of mice injected with cell wall fractions. 


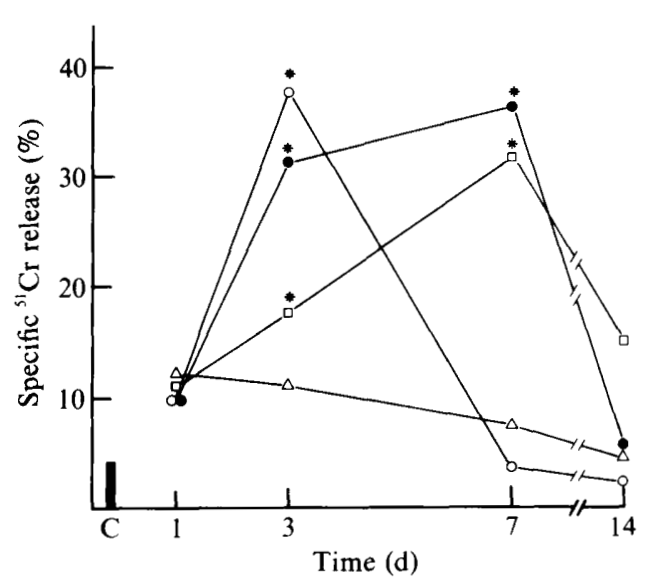

Fig. 1

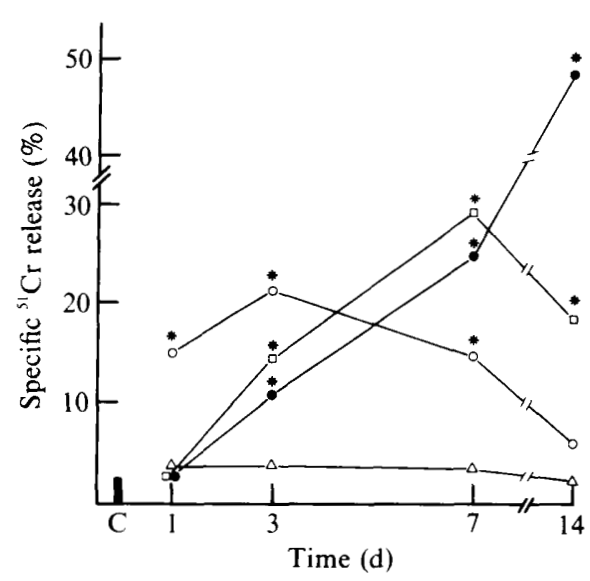

Fig. 2

Fig. 1. Cytotoxic, anti-YAC-1 activity of PEC from mice treated with $\mathrm{CA}(\boldsymbol{O})$ or cell wall fractions (MP, O; GG, $\square$; M-alk, $\triangle$ ). CD2Fl mice were injected intraperitoneally with $5 \times 10^{7}$ cells (CA) or with $1 \mathrm{mg}$ (GG) or $0.01 \mathrm{mg}$ (MP and M-alk) of cell wall fraction. The PEC were harvested from 1 to $14 \mathrm{~d}$ later and assayed with ${ }^{51} \mathrm{Cr}$-labelled YAC-1 target cells at an effector:target ratio of $100: 1$. The solid bar $(C)$ indicates the specific release induced by PEC from untreated, control mice. The asterisks indicate highly significant differences $(P<0.01)$ in the cytotoxic activity of PEC from treated mice compared with untreated controls. The data are from a typical experiment out of six performed, using different batches of cells and cell wall fractions, with essentially similar results.

Fig. 2. Cytotoxic, anti-P-815 activity of PEC from mice treated with CA (O) or cell wall fractions (MP, $\mathrm{O}$; GG, $\square$; M-alk, $\triangle$ ). CD2F1 mice were injected intraperitoneally with $5 \times 10^{7}$ cells (CA) or with $1 \mathrm{mg}$ (GG) or $0.01 \mathrm{mg}$ (MP and M-alk) of cell wall fraction. The PEC were harvested from 1 to $14 \mathrm{~d}$ later and assayed with ${ }^{51} \mathrm{Cr}$-labelled P-815 target cells $(18 \mathrm{~h})$ at an effector : target ratio of $50: 1$. The solid bar $(C)$ indicates the specific release induced by $P E C$ from untreated, control mice. The asterisks indicate highly significant $(P<0.01)$ differences in the cytotoxic activity of PEC from treated mice compared to untreated controls. The data are from a typical experiment out of four performed with essentially similar results.

Separation of PEC in Percoll-density gradients confirmed that a large proportion of PEC harvested from mice injected with $\mathrm{CA}$, or with MP or GG fractions, banded in low-density Percoll components which were, on morphological analysis, highly enriched in large granular lymphocytes (data not shown).

\section{Effect of inoculation of intact $C$. albicans cells $(C A)$ and cell wall components on the anti-YAC-1 activity of $P E C$}

To study the effect of CA and its cell wall fractions on the generation of natural cytotoxic immunoeffectors in mice, we first tested the PEC harvested from mice given the various $C$. albicans materials for their capacity to lyse YAC-1 tumour cells in an in vitro short-term ${ }^{51} \mathrm{Cr}$ release assay. Preliminary experiments served to determine the optimal dose of each material required to induce cytotoxic cells. As shown in Table 3, CA, MP and GG induced cytotoxic cells highly effective in lysing YAC-1 cells in vitro, the optimum being detected after injection of $1 \mathrm{mg}, 0.01 \mathrm{mg}$ and $1 \mathrm{mg}$ per mouse, respectively. Conversely, no or barely detectable antiYAC-1 activity was induced in PEC from mice given $M$-alk or $M$ fractions, whatever the injected dose.

The kinetics of induction of cytotoxic PEC differed for each active material. In particular, the highest cytotoxic activity of PEC from MP-treated mice was detected on day 3 after treatment whereas GG-treated animals showed the highest cytotoxic PEC on day 7 after injection. Interestingly, PEC from CA-injected mice had high lytic activity throughout the 3-7 d period after treatment. Fig. 1 shows the data from a typical experiment.

Functional and phenotypic characteristics of the anti-YAC-1 effectors generated by MP and GG fractions of $C$. albicans cells are shown in Table 4 . The effectors were non-adherent and non- 


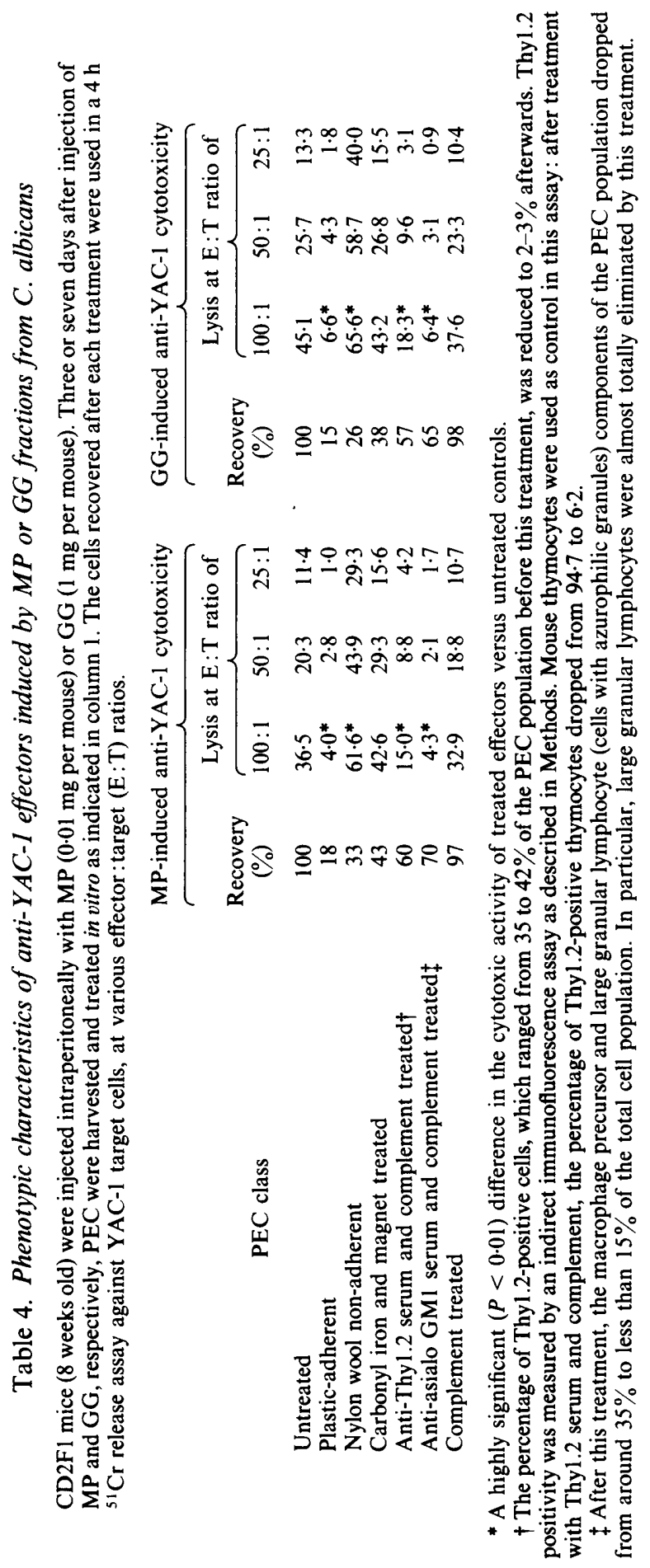


phagocytic and, similar to the anti-YAC-1 PEC induced by whole C. albicans cells (Marconi et al., 1985), they were partially sensitive to anti-Thy 1.2 serum and totally sensitive to anti-asialo GM1 antibodies plus complement. These effectors were also unable to lyse the NK-resistant cell lines MBL-2 or EL-4 in a $4 \mathrm{~h}^{51} \mathrm{Cr}$ release assay done at an effector : target ratio of $50: 1$ (data not shown).

\section{Effect of inoculation of intact $C$. albicans cells $(C A)$ and cell wall components on the anti-P-815 activity of PEC}

An experimental protocol similar to that reported in the preceding section was adopted to determine whether PEC elicited by injection of $C$. albicans materials were also capable of lysing the P-815 cell line, a classical target of murine activated macrophages (Schreiber et al., 1986). This possibility was suggested by the observation (see Table 2) that the inoculation of C.albicans materials elicited PEC with high numbers of cells morphologically compatible with monocytemaciophage lineage. In these experiments, an $18 \mathrm{~h}{ }^{51} \mathrm{Cr}$ release assay was used, at different effector : target ratios. A roughly linear, time-dependent increase in anti-P-815 cytotoxic activity was detected in PEC following injection of CA (Fig. 2). Significant lytic activity was also observed with PEC stimulated with GG. A lower anti-P-815 cytotoxicity was shown by MPinduced PEC (no activity was detected on day 14 in this case) and, again, no significant cytotoxicity was raised in PEC from mice injected with M-alk.

A limited characterization of the anti-P-815 peritoneal effectors induced by $C$. albicans materials was also attempted. These effectors were plastic-adherent, phagocytic and fully insensitive to treatment with the anti-Thyl.2 serum.

\section{DISCUSSION}

In the search for separate fractions of $C$. albicans which could mediate the potent NKinducing activity of whole yeast cells, we prepared components enriched in the principal cell wall materials of this micro-organism. These components were tested for their ability to induce peritoneal cytotoxic immunoeffectors in mice. The experiments consistently demonstrated that two fractions (MP and GG) of $C$. albicans induced the generation/recruitment of murine cytotoxic effectors. The two fractions differed markedly in the kinetics of induction of peritoneal cytotoxic effectors. In general, the effect of GG (like that of whole $C$. albicans cells) was of longer duration and, at least for the anti-P-815 activity, more intense than that obtained with MP injection. However, the functional and phenotypic characteristics of the effectors generated by each fraction were similar to those induced by whole cells (Marconi et al., 1985). The anti-YAC-1 effectors were non-adherent, non-phagocytic, partially sensitive to anti-Thy 1.2 serum and totally sensitive to anti-asialo GM1 antibodies, all properties which are typical of murine NK lymphocytes (Herberman \& Ortaldo, 1981; Jimenez \& Murphy, 1984). Macrophage precursors which are indistinguishable morphologically or in staining properties from large granular lymphocytes could also lyse YAC-1 cells. However, they lack high-density asialo-GM1 determinants and Thy antigen (Baccarini et al., 1985), and therefore are probably not responsible for the anti-YAC-1 activity reported here. On the other hand, the effectors which were capable of lysing in vitro a well-known NK-resistant target such as the P-815 mastocytoma cell line were found to be adherent, phagocytic and insensitive to the anti-Thy 1.2 serum plus complement treatment. On this basis, activated macrophages are probably responsible for the anti-P-815 activity reported here. Both intact $C$. albicans cells and yeast glucan have already been reported to be strong macrophage activators both in vivo and in vitro (Kokoshis et al., 1978; Weinberg \& Hibbs, 1979; Reynolds et al., 1980; Seljelid et al., 1981) and it is generally believed that the antitumour and/or the anti-infectious properties of yeast glucan are due to activated macrophages (Mansell et al., 1976; Reynolds et al., 1980). The experiments with glucan from $C$. albicans confirm previous observations but also suggest that NK effectors might additionally be involved in the protective effects of glucan.

Much of the work reported in this paper was aimed at detecting the active component(s), if any, of $C$. albicans cell wall which could mediate the potent NK- and macrophage-stimulating 
activity possessed by whole micro-organisms. Therefore, the chemical composition and antigenic properties of both the MP extract and GG fraction were critically considered. The MP extract contained mannose as predominant sugar together with glucose and ribose as minor sugar constituents. Protein was also present. MP reacted strongly with anti-C. albicans sera. The quantitative ELISA-inhibition reaction showed that MP did not significantly differ from a classical mannan preparation in binding to anti-mannan antibodies. Our MP extract therefore basically consists of a mannoprotein complex or mixture. Other non-polysaccharide, nonprotein materials are likely to be present as minor contaminants of the MP fraction, but protein plus polysaccharide constitutes about $98 \%$ of the total weight of the fraction. As the MP extract exerts its optimum biological activity at a dose of only $10 \mu \mathrm{g}$ per mouse, any unknown contaminant would be active at doses around $0 \cdot 1 \mu \mathrm{g}$; that is possible, but unlikely. Preliminary experiments have demonstrated the presence of three to four distinct mannoprotein components in an MP complex separated by DEAE-Sephadex A50 gel chromatography. Whether each of these components or only one of them is the immunoactive material is currently under investigation.

The other two fractions of $C$. albicans ( $\mathrm{M}$ and $\mathrm{M}$-alk) which also contained mannan as predominant component, but which had either a low protein content (M) or alkali-degraded material (M-alk), were inactive in the induction of peritoneal cytotoxicity.

The immunoactive fraction GG obtained by recovery of the insoluble glucan fraction of the cell wall was almost exclusively composed of glucose and did not react with anti-mannan antibodies. Therefore, both the present experimental evidence and past studies (Cassone et al., 1978,1981 ) suggest that GG represents the insoluble $\beta$-glucan component of the $C$. albicans cell wall. Since the optimal induction of cytotoxic PEC by GG was seen when it was injected at a relatively high dose ( $1 \mathrm{mg}$ per mouse), whereas the most effective dose of MP was $0.01 \mathrm{mg}$ per mouse, the effect of GG might be due to the presence of a residual mannoprotein in this fraction. However, the two materials differed in the kinetics of cytotoxicity induction, and the procedure adopted to obtain the insoluble glucan ghosts $(\mathrm{GG})$, involving cycles of hot alkali-acid extraction, is likely to extract/hydrolyse most if not all of the mannoprotein components. Moreover, the M-alk fraction, obtained through a single hot alkali treatment, was inactive, although containing both mannan and proteins. Finally, an ELISA inhibition assay capable of detecting 1-2 ng mannan $\mathrm{ml}^{-1}$ did not reveal any trace of mannan in up to $300 \mathrm{ng}$ of GG. Other non-mannoprotein contaminants could be present in this fraction, but it is unlikely that their biological activity was preserved after repeated vigorous hot alkali-acid treatments.

Thus, at least two of the cell wall constituents of $C$. albicans, i.e. the mannoprotein and the insoluble glucan, can stimulate in vivo generation of cytotoxic cells (either NK or macrophage effectors) in mice. The powerful activity of $C$. albicans as a biological response modifier may have important implications if we consider that the cytotoxic cells elicited by $C$. albicans constituents play important roles in the control of microbial pathogens and tumour growth.

The work described in this paper was supported in part by CNR (Italy) grants under contract nos 85.02557.44 and 86.02680.44, Special Project 'Oncologia'. The authors wish to thank Mrs A. M. Diodovich for helpful assistance in manuscript preparation.

\section{REFERENCES}

Albersheim, P., Nevius, D. J., English, P. D. \& CARR, A. (1967). A method for the analysis of sugars in plant cell-wall polysaccharides by gas-liquid chromatography. Carbohydrate Research 5, 340-345.

ausizllo, C. M., Spagnoli, G. C., Boccanera, M., Casalinuovo, I., Malavasi, F., Casciani, C. U. \& CAssone, A. (1986). Proliferation of human peripheral blood mononuclear cells induced by Candida albicans and its cell wall fractions. Journal of Medical Microbiology 22, 195-202.

Baccarini, M., Bistoni, F. \& Lohman-Matthes, M. L. (1985). In vitro natural cell-mediated cytotoxicity against Candida albicans: macrophage precur- sors as effector cells. Journal of Immunology 134, 2658-2665.

Bistoni, F., Vecchiarelli, A., Cenci, E., Puccetti, P., MarConi, P. \& Cassone, A. (1986). Evidence for macrophage-mediated protection against a lethal Candida albicans infection. Infection and Immunity 51, 668-674.

Cassone, A., Mattia, E. \& Boldrini, L. (1978). Agglutination of blastospores of Candida albicans by Concanavalin $\mathrm{A}$ and its relationship with the distribution of mannan polymers and the ultrastructure of the cell wall. Journal of General Microbiology 105, 263-273. 
Cassone, A., Kerridge, D. \& Gale, E. F. (1979). Ultrastructural changes in the cell wall of Candida albicans following cessation of growth and their possible relationship to the development of polyene resistance. Journal of General Microbiology 110, 339349.

Cassone, A., Marconi, P., Bistoni, F., Mattia, E., Sbaraglia, G., Garaci, E. \& Bonmassar, E. (1981). Immunoadjuvant effects of Candida albicans and its cell wall fractions in a mouse lymphoma model. Cancer Immunology and Immunotherapy 10, 181-190.

Chen, P. S., Toribara, T. Y. \& Warner, H. (1956). Microdetermination of phosphorus. Analytical Chemistry 28, 1756-1758.

Cikes, M., Friberg, S. \& Klein, G. (1973). Progressive loss of $\mathrm{H}-2$ antigen with concomitant increase of cell surface antigen(s) determined by Moloney leukemia virus in cultured murine lymphomas. Journal of the National Cancer Institute 50, 347-351.

Cutler, J. E. \& Lloyd, R. K. (1983). Enhanced antibody response induced by Candida albicans in mice. Infection and Immunity 38, 1102-1108.

Domer, J. E., Stashak, P. W., Elkins, K., Prescott, B., Caldes, G. \& Baker, P. J. (1986). Separation of immunomodulatory effects of mannan from Candida albicans into stimulatory and suppressive components. Cellular Immunology 101, 403-414.

Dubois, M., Gilles, K. A., Hamilton, J. K., Rebers, P. A. \& SMith, F. (1956). Colorimetric method for determination of sugars and related substances. Analytical Chemistry 28, 350-356.

Gilbertson, S. M., Shah, P. D \& Rowley, D. R. (1986). NK cells suppress the generation of Lyt-2 $2^{+}$ cytolytic $\mathrm{T}$ cells by suppressing or eliminating dendritic cells. Journal of Immunology 136, 35673571 .

Herberman, R. B. \& Ortaldo, J. R. (1981). Natural killer cells: their role in defense against disease. Science 24, 24-30.

JimeneZ, B. E. \& MURPHY, J. W. (1984). In vitro effects of natural killer cells against Paracoccidioides brasiliensis yeast phase. Infection and Immunity 46, 552-558.

Julius, M. H., Simpson, E. \& HerzenberG, L. A (1973). A rapid method for the isolation of functional thymus-derived murine lymphocytes. European Journal of Immunology 3, 645-652.

Kasai, M., IWAmori, M., Nagai, Y., OKomura, K. \& TODA, T. (1980). A glycolipid on the surface of mouse natural killer cells. European Journal of Immunology 10, 175-181

Kokoshis, P. L., Williams, D. L., Cook, J. A. \& Di LUZIo, N. R. (1978). Increased resistance to Staphylococcus aureus infection and enhancement of serum lysozyme activity by glucan. Science 199, 1340-1342.

Landolfo, S., Herberman, R. B. \& Holden, H. T. (1978). Macrophage-lymphocyte interaction in migration-inhibition factor (MIF) production against soluble or cellular tumor-associated antigens. I. Characteristics and genetic control of two different mechanisms of stimulating MIF production. Journal of Immunology 121, 695-701.

Manseli, P. W. A., Di Luzio, N. R., MCNamee, R., Rowden, G. \& Proctor, J. W. (1976). Recognition factors and non-specific macrophage activation in the treatment of neoplastic disease. Annals of the New York Academy of Sciences 277, 20-44.
Marconi, P., Cassone, A., Baccarini, M., Tissi, L., Garaci, E., Bonmassar, E., Frati, L. \& Bistoni, F. (1983). Relationship between tumor load, route of tumor inoculation and response to immunotherapy in a murine lymphoma model. Journal of the National Cancer Institute 71, 299-335.

Marconi, P., Scaringi, L., Tissi, L., Boccanera, M., Bistoni, F., Bonmassar, E. \& Cassone, A. (1985). Induction of natural killer cell activity by inactivated Candida albicans in mice. Infection and Immunity $\mathbf{5 0}$, 297-303.

Mattia, E. \& CASSONE, A. (1979). Inducibility of germtube formation in Candida albicans at different phases of yeast growth. Journal of General Microbiology 113, 439-441.

Peat, S., Whelan, W. J. \& Edwards, T. E. (1961). Polysaccharides of baker's yeast. Part IV. Mannan. Journal of the Chemical Society 29-34.

Reynolds, J. A., Kastello, M. D., Harrington, D. H., Crobbs, C. L., Peters, C. J., Jenski, J. V., ScotT, G. H. \& Di Luzio, N. R. (1980). Glucaninduced enhancement of host resistance to selected infectious diseases. Infection and Immunity 30, 51-57.

Rogers, T. J. \& BALISH, E. (1980). Immunity to Candida albicans. Microbiological Reviews 44, 660 684.

Santoni, A., Piccoli, M., Ortaldo, J. R., Mason, L., Wiltrout, R. H. \& Herberman, R. B. (1985). Changes in number and density of large granular lymphocytes upon in vivo augmentation of mouse natural killer activity. Journal of Immunology 134, 2799-2810.

Schreiber, R. D., Celada, A. \& Buchmeier, N. (1986). The role of interferon-gamma in the induction of inactivated macrophages. Annales de l'Institut Pasteur/Immunologie 137C, 203-206.

Seljelid, R., Bogwald, J. \& Lundwall, A. (1981). Glycan stimulation of macrophages in vitro. Experimental Cell Research 131, 121-129.

SUTHERland, I. W. \& WILKINSON, J. F. (1971). Chemical extraction methods of microbial cells. Methods in Microbiology 5B, 345-383.

Tartof, D., Check, L. J., Matutis, A., Hunter, R. L. \& FITCH, F. W. (1980). Studies on stimulation of cellmediated cytotoxicity by skin test antigens. Journal of Immunology 125, 2790-2796.

Tartof, D., Curran, J. J., LeVitT, D. \& Loken, M. R. (1983). The skin test antigen stimulated killer (STAK) cell mediating NK like CMC is OKM1 positive and OKT3 negative. Clinical and Experimental Immunology 54, 561-566.

WEINBERG, J. B. \& HibBs, J. B. (1979). Enhanced macrophage tumoricidal activity and tumor suppression or regression caused by heat-killed Candida albicans. Journal of the National Cancer Institute 63, 1273-1278.

Williams, D. L., Cook, J. A., Hoffman, E. O. \& Di Luzio, N. R. (1978). Protective effect of glucan in experimentally-induced candidiasis. Journal of the Reticuloendothelial Society 23, 479-490.

Zang, S. R., Salup, R. S., Urias, P. E., Twillie, T. A., Talmadge, J. E., Herberman, R. B. \& Wiltrout, R. H. (1986). Augmentation of NK activity and/or macrophage-mediated cytotoxicity in the liver by biological response modifiers including human recombinant interleukin-2. Cancer Immunology and Immunotherapy 21, 19-25. 